Proceedings

\title{
Spearman Correlation between the NDVI and Quercus Airborne Pollen in the SW of the Iberian Peninsula ${ }^{\dagger}$
}

\author{
Rocío González-Naharro 1, Elia Quirós 1, Santiago Fernández-Rodríguez 2,*, \\ Inmaculada Silva-Palacios ${ }^{3}$, Rafael Tormo-Molina ${ }^{4}$, José María Maya-Manzano ${ }^{5}$, \\ Alejandro Monroy-Colin ${ }^{4}$, Raúl Pecero-Casimiro ${ }^{4}$ and Ángela Gonzalo-Garijo ${ }^{6}$ \\ 1 Department of Graphic Expression, School of Technology, University of Extremadura, Avda. de la \\ Universidad s/n, 10003 Cáceres, Spain; rgonzalebn@alumnos.unex.es (R.G.-N.); equiros@unex.es (E.Q.) \\ 2 Department of Construction, School of Technology, University of Extremadura, Avda. de la Universidad \\ s/n, 10003 Cáceres, Spain \\ 3 Department of Applied Physics, Engineering Agricultural School, University of Extremadura, Avda. Adolfo \\ Suárez s/n, 06006 Badajoz, Spain; insilva@unex.es \\ 4 Department of Plant Biology, Ecology and Earth Sciences, Faculty of Science, University of Extremadura, \\ Avda. Elvas s/n, 06006 Badajoz, Spain; ratormo@unex.es (R.T.-M.); bioamc@outlook.com (A.M.-C.); \\ raulpc@unex.es (R.P.-C.) \\ 5 School of Chemical and Pharmaceutical Sciences, Dublin Institute of Technology, Kevin Street, \\ Dublin D08X622, Ireland; jmmaya@unex.es \\ 6 Department of Allergology, Infanta Cristina University Hospital, Avda. Elvas s/n, 06006 Badajoz, Spain; \\ magonzalog@gmail.com \\ * Correspondence: santiferro@unex.es; Tel.: +34-927-257000 \\ + Presented at Environment, Green Technology and Engineering International Conference (EGTEIC 2018), \\ Caceres, Spain, 18-20 June 2018.
}

Published: 7 November 2018

\begin{abstract}
New space technologies as Advanced Very High Resolution Radiometer (AVHRR) and the MODerate resolution Imaging Spectroradiometer (MODIS) have been used to display several phenological cycles of ecosystems around the world. The aim of this study was to establish the relationship between Normalized Difference Vegetation Index, NDVI, associated to oak trees within three training data polygons (15, 25 and $50 \mathrm{~km}$-distance to the volumetric sampler Hirst), and the daily average Quercus airborne pollen concentrations in 20 years. The study was developed in Badajoz (SW Iberian Peninsula) with a continuous pollen recording in the period from 1994 to 2013. The main novelty of this study has been the analysis of the correlation between the two-time series, using Spearman test. Within the 20 studied years, 12 years obtained significant values in the Spearman test in the whole studied area.
\end{abstract}

Keywords: Normalized Difference Vegetation Index (NDVI); Quercus airborne pollen; Polygon oak trees; Spearman correlation; Pollination phenology

\section{Introduction}

Land cover changes and plant phenological response have been attributed to the impact of human activity on plant distribution [1]. NDVI and its relation with pollen grains seems to be considered as a topic increasingly popular due to their multiple applications in issues such as dispersal processes with the ecological scaling [2], phenological phenomena with the start days of birch pollen seasons [3], real-time monitoring with short-term forecasting of land surface phenology [4] or for long term data in a 20-year study of NDVI variability [5]. Many other applications of NDVI regarding 
pollen have been maps: satellite-based map of onset of birch (Betula) flowering [6], and for identifying urban sources as cause of elevated grass pollen concentrations using GIS and remote sensing [7].

Mediterranean forest derived ecosystems in the SW of the Iberian Peninsula are named "savannah-like ecosystems" and formed, mainly, by tree species of the genus Quercus (oak) with five species as the most common: Quercus ilex subsp. ballota ( $=$ Q. rotundifolia), Q. suber, Q. pyrenaica, $Q$. coccifera and $Q$. faginea [8]. Those trees in the study area dominate natural and seminatural landscapes, only in Extremadura dehesas represent 34\% of surface [9]. Potential Natural Vegetation (PNV) is analyzed by the size-frequency distribution polygons of soil and vegetation maps [10]. The use of polygons to delimit space units is widely used for riparian vegetation [11], for assessing different feature set's effects of land cover classification [6] and the relationship between this land cover surface and pollen grain concentrations for different wind direction patterns [12]. The aim of this study was to establish the relationship between NDVI associated to oak trees within three training data polygons (15, 25 and $50 \mathrm{~km}$-distance to the volumetric sampler Hirst) and the daily average Quercus airborne pollen concentrations for 20 years of continuous recording (1994-2013) from an urban area in the SW of the Mediterranean region. Spearman correlation has been used to accomplish the goal.

\section{Material and Methods}

\subsection{Sampling Site}

The study area was located in Badajoz (SW Spain) in the border with Portugal. The training extent was encompassed in a diameter of 15, 25 and $50 \mathrm{~km}$ around a 7-day volumetric sampler pollen [13]. Sampling point was located $\left(38^{\circ} 53^{\prime} 45^{\prime \prime} \mathrm{N}, 6^{\circ} 58^{\prime} 07^{\prime \prime} \mathrm{W}\right)$ on a terrace at $6 \mathrm{~m}$ above ground in a building of the Agricultural Engineering School of the University of Extremadura with Quercus pollen data from 20 years (1994-2013).

\subsection{Space Images NDVI NOAA/ AVHRR}

NDVI image records can be accessed through the United States Geological Survey (USGS). Daily data offered by the service includes the period from 1981 to 2013 in the website https://earthexplorer.usgs.gov/. In order to establish the NDVI images to be studied, the total days of Quercus Main Pollen Season (MPS) between 1994 and 2013 were calculated, based on the previous study by Fernández-Rodríguez et al. [14]. These Quercus MPS were estimated using the 5-95\% range defined by [15].

\subsection{Cartography}

Due to the fact that our study area is located in the border between Spain and Portugal, it was necessary to use two different cartographic sources: in the Spanish part of the study, the Extremadura Forest Map (MFEx) has been used, while in the Portuguese part, data of the Fifth National Forest Inventory of Portugal (IFN5) concerning oak and cork oak locations were employed. This IFN5 information was provided by the Autoridade Florestal Nacional (AFN) (2010) and belongs to the National Forest Inventory 2005-06, Continental Portugal-IFN5 2005-2006, Lisbon.

\subsection{Statistical Analysis}

The relationship between Quercus pollen concentration and NDVI was correlated by Spearman test.

\section{Results}

The correlation was statistically studied using the Spearman test. The results forthcoming from the Spearman correlation test (Table 1) show those years 1996, 1999 and 2012 had non-significant correlations with pollen concentration within the three training areas. Additionally, years 1994, 2000 
and 2006 had few significant correlations in only one training area, having substantial dispersions in the other training areas.

Table 1. Statistical Spearman test results in the three training areas (significant correlations in bold).

\begin{tabular}{|c|c|c|c|c|c|c|c|}
\hline \multirow[b]{2}{*}{ Year } & \multirow[b]{2}{*}{ LAGS } & \multicolumn{2}{|c|}{$50 \mathrm{Km}$} & \multicolumn{2}{|c|}{$25 \mathrm{Km}$} & \multicolumn{2}{|c|}{$15 \mathrm{Km}$} \\
\hline & & $\begin{array}{l}\text { Spearman } \\
\text { Correlation }\end{array}$ & $\begin{array}{c}\text { Spearman } \\
p \text {-Value }\end{array}$ & $\begin{array}{l}\text { Spearman } \\
\text { Correlation }\end{array}$ & $\begin{array}{c}\text { Spearman } \\
p \text {-Value }\end{array}$ & $\begin{array}{l}\text { Spearman } \\
\text { Correlation }\end{array}$ & $\begin{array}{c}\text { Spearman } \\
p \text {-Value }\end{array}$ \\
\hline 1994 & 9 & 0.3510 & 0.0080 & 0.3220 & 0.0160 & 0.3120 & 0.0190 \\
\hline 1995 & 8 & 0.5320 & $<0.0001$ & 0.3490 & 0.0100 & 0.2870 & 0.0360 \\
\hline 1996 & 1 & 0.2070 & 0.1380 & 0.1920 & 0.1690 & 0.1450 & 0.3000 \\
\hline 1997 & 1 & 0.5930 & $<0.0001$ & 0.6340 & $<0.0001$ & 0.5760 & $<0.0001$ \\
\hline 1998 & 10 & 0.3910 & 0.0010 & 0.3810 & 0.0020 & 0.0970 & 0.4390 \\
\hline 1999 & 1 & 0.0900 & 0.5200 & 0.1480 & 0.2890 & 0.0830 & 0.5550 \\
\hline 2000 & 12 & 0.2170 & 0.1040 & 0.2200 & 0.0460 & 0.1480 & 0.2710 \\
\hline 2001 & 4 & 0.5210 & $<0.0001$ & 0.5060 & $<0.0001$ & 0.5000 & $<0.0001$ \\
\hline 2002 & 1 & 0.4280 & 0.0010 & 0.5330 & $<0.0001$ & 0.3940 & 0.0020 \\
\hline 2003 & 11 & 0.3060 & 0.0060 & 0.3000 & 0.0070 & 0.2550 & 0.0220 \\
\hline 2004 & 4 & 0.2820 & 0.0410 & 0.4060 & 0.0030 & 0.3570 & 0.0090 \\
\hline 2005 & 12 & 0.4820 & 0.0000 & 0.5210 & $<0.0001$ & 0.3510 & 0.0060 \\
\hline 2006 & 15 & 0.2290 & 0.0470 & 0.1080 & 0.3510 & 0.1030 & 0.3770 \\
\hline 2007 & 13 & 0.3190 & 0.0060 & 0.3370 & 0.0040 & 0.3220 & 0.0060 \\
\hline 2008 & 7 & 0.4370 & 0.0010 & 0.4400 & 0.0010 & 0.4160 & 0.0020 \\
\hline 2009 & 6 & 0.2570 & 0.0460 & 0.2580 & 0.0450 & 0.2800 & 0.0290 \\
\hline 2010 & 9 & 0.2520 & 0.0620 & 0.3260 & 0.0150 & 0.3500 & 0.0080 \\
\hline 2011 & 1 & 0.6080 & 0.0000 & 0.6060 & 0.0000 & 0.5950 & 0.0000 \\
\hline 2012 & 13 & 0.0350 & 0.7580 & -0.0480 & 0.6740 & -0.2030 & 0.0720 \\
\hline 2013 & 9 & 0.4690 & 0.0000 & 0.4790 & 0.0000 & 0.4490 & 0.0010 \\
\hline
\end{tabular}

\section{Conclusions}

The main novelty of this study has been the analysis of the correlation between the value NDVI of holm oaks and cork oaks (Quercus rotundifolia and Quercus suber) inside to the regional scale with short distances: remote urban $(50 \mathrm{~km})$, peri-uban $(25 \mathrm{~km})$ and urban areas $(15 \mathrm{~km})$ with Quercus airborne pollen for a long term data (1994-2013) in the SW Iberian Peninsula, using Spearman correlation test. Within the 20 studied years, 12 years obtained significant values in the Spearman test in the whole studied area. Differences found between years could be explained due to meteorology without discarding the influence of long distance airborne pollen transport. Future studies are proposed with phenological and meteorological data and other types of pollen grains for trying to get better not only a short-term, but also real-time monitoring could be implemented for forecasting pollen concentrations.

Author Contributions: D.I.-S., R.-T.M., D.Á.G.-G., J.M.M.-M., A.M.-C. and R.P.-C. conceived and designed the experiments; R.G.-N. performed the experiments; D.E.Q. analyzed the data; D.E.Q. contributed reagents/materials/analysis tools; E.Q. and S.F.-R. wrote the paper.

Acknowledgments: This work was possible by funds from research projects PRIIB16029 and research groups aid GR15060 financed by the Regional Government, Junta de Extremadura (Spain) and the European Regional Development Fund. The authors want to thank the support of LTER Montado site (LTER Portugal network) for the contribution of cartographic data of the Fifth National Forest Inventory of Portugal (IFN5) concerning oak and cork oak locations.

Conflicts of Interest: The authors declare no conflict of interest. 


\section{References}

1. García-Mozo, H.; Oteros, J.A.; Galán, C. Impact of land cover changes and climate on the main airborne pollen types in Southern Spain. Sci. Total Environ. 2016, 548-549, 221-228.

2. Gage, S.H.; Isard, S.A.; Colunga-G, M. Ecological scaling of aerobiological dispersal processes. Agric. For. Meteorol. 1999, 97, 249-261.

3. Hogda, K.A.; Karlsen, S.R.; Solheim, I.; Tommervik, H.; Ramfjord, H. The start dates of birch pollen seasons in Fennoscandia studied by NOAA AVHRR NDVI data. Int. Geosci. Remote Sens. Symp. (IGARSS) 2002, 6, 3299-3301.

4. White, M.A.; Nemani, R.R. Real-time monitoring and short-term forecasting of land surface phenology. Remote Sens. Environ. 2006, 104, 43-49.

5. Barbosa, H.A.; Huete, A.R.; Baethgen, W.E. A 20-year study of NDVI variability over the Northeast Region of Brazil. J. Arid Environ. 2006, 67, 288-307.

6. Karlsen, S.R.; Ramfjord, H.; Høgda, K.A.; Johansen, B.; Danks, F.S.; Brobakk, T.E. A satellite-based map of onset of birch (Betula) flowering in Norway. Aerobiologia 2009, 25, 15-25.

7. Skjøth, C.A.; Ørby, P.V.; Becker, T.; Geels, C.; Schlünssen, V.; Sigsgaard, T.; Bønløkke, J.H.; Sommer, J.; Søgaard, P.; Hertel, O. Identifying urban sources as cause of elevated grass pollen concentrations using GIS and remote sensing. Biogeosciences 2013, 10, 541-554.

8. J.M. Maya-Manzano, S. Fernández-Rodríguez, M. Smith, R. Tormo-Molina, A. Reynolds, I. Silva-Palacios, Á. Gonzalo-Garijo, M. Sadyś, Airborne Quercus pollen in SW Spain: Identifying favourable conditions for atmospheric transport and potential source areas. Sci. Total Environ. 2016, 571, 1037-1047.

9. Morillo, J.; Espejo, A.M. Determinación de la superficie ocupada por las áres adhesada en Extremadura. Ed. La agricultura y la ganadería extremeñas en 2007. Junta de Extremadura. 2008. Informe 2007. La agricultura y la ganadería extremeña. Facultad de Ciencias Económicas Empresariales. Escuela de Ingenierías Agrarias. Universidad de Extremadura. Servicio de Publicaciones de la Universidad de Extremadura. Caja de Badajoz. Badajoz (Extremadura).

10. Ibáñez, J.J.; Gómez, R.P. Diversity of Soil-Landscape Relationships: State of the Art and Future Challenges. In Geopedology: An Integration of Geomorphology and Pedology for Soil and Landscape Studies; Zinck, J.A., Metternicht, G., Bocco, G., del Valle, H.F., Eds.; Springer International Publishing: Cham, Switzerland, 2016; pp. 183-191.

11. Wang, J.; Zhang, Z.; Greimann, B.; Huang, V. Application and evaluation of the HEC-RAS-Riparian vegetation simulation module to the Sacramento River. Ecol. Model. 2018, 368, 158-168.

12. J.M. Maya-Manzano, R. Tormo-Molina, S. Fernández-Rodríguez, I. Silva-Palacios, Á. Gonzalo-Garijo, Distribution of ornamental urban trees and their influence on airborne pollen, Landscape and Urban Planning 157 (2017) 434-446.

13. J.M. Hirst, An automatic volumetric spore trap. Ann. Appl. Biol. 1952, 39, 257-265.

14. Fernández-Rodríguez, S.; Durán-Barroso, P.; Silva-Palacios, I.; Tormo-Molina, R.; Maya-Manzano, J.M.; Gonzalo-Garijo, Á. Quercus long-term pollen season trends in the southwest of the Iberian Peninsula. Process Saf. Environ. Prot. 2016, 101, 152-159.

15. Nilsson, S.; Persson, S. Tree pollen spectra in the Stockholm region (sweden), 1973-1980. Grana 1981, 20, 179-182.

(C) 2018 by the authors. Licensee MDPI, Basel, Switzerland. This article is an open access article distributed under the terms and conditions of the Creative Commons Attribution (CC BY) license (http://creativecommons.org/licenses/by/4.0/). 